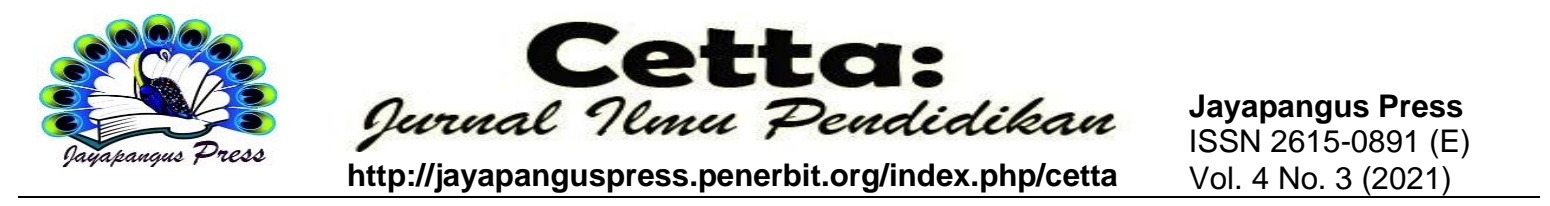

\title{
Hambatan Dan Kendala Dalam Pelaksanaan Pembelajaran Daring Pasca Covid-19
}

\author{
Ni Made Arini' ${ }^{1}$, Ida Bagus Alit Arta Wiguna ${ }^{2}$ \\ Institut Agama Hindu Negeri Gde Pudja Mataram \\ ${ }^{1}$ arini@iahn-gdepudja.ac.id, ${ }^{2}$ gusarta@iahn-gdepudja.ac.id
}

\begin{tabular}{l}
\hline Keywords: \\
\hline Online Learning; \\
Covid-19 \\
\hline
\end{tabular}

\begin{abstract}
The pandemic Covid-19 has made major changes in almost all aspects of human life, one of which is the education system. Changes in the education system are forced to make it difficult for students to take courageous learning and accept learning materials, especially students at an early age, because learning that is usually done conventionally becomes learning that is free to change, with its implementation inseparable from the role of teachers and technology. This research aims to examine the obstacles and obstacles faced by teachers in carrying out bold learning after Covid-19. The method in this study uses a qualitative method with exploratory characteristics. The results and conclusions in this paper indicate that the obstacles and obstacles when learning courage is that the teacher is not used to it and does not have interesting learning materials to carry out bold learning. The obstacle is the limited information and government, regarding the provision of assistance for school health service facilities.
\end{abstract}

Kata Kunci:

Pembelajaran

Daring;

Covid-19

\begin{abstract}
Abstrak
Pandemi Covid-19 membuat terjadinya perubahan besar mencakup hampir diseluruh aspek kehidupan manusia salah satunya pada sistem pendidikan. Perubahan sistem pendidikan secara terpaksa menyebabkan para siswa menjadi sulit untuk mengikuti pembelajaran daring serta menerima materi pembelajaran, terlebih para siswa di jenjang anak usia dini, dikarenakan pembelajaran yang biasanya dilakukan secara konvensional anak bisa bermain dengan bebas berubah menjadi pembelajaran daring, dengan pelaksanaannya tidak dapat terlepas dari peran guru dan teknologi. Penelitian ini bertujuan untuk mengkaji apasaja hambatan dan kendala yang dihadapi oleh guru dalam melaksabakan pembelajaran daring pasca Covid-19. Metode dalam penelitian ini menggunakan metode kualitatif dengan karakteristik yang bersifat eksploratif. Hasil dan kesimpulan dalam penulisan ini menunjukkan bahwa hambatan dan kendala saat pembelajaran daring adalah guru belum terbiasa dan tidak memiliki bahan ajar yang menarik untuk melaksanakan pembelajaran daring. Kendalanya adalah
\end{abstract}


keterbatasan informasi dan birokrasi pemerintahan, mengenai penyediaan bantuan pemenuhan fasilitas protokol kesehatan sekolah.

\section{Pendahuluan}

Penyebaran Pandemi Covid-19 Semakin banyak yang terjangkit dari bulan juli hingga agustus tahun 2021 sehingga pemberlakuan PPKM Level 4 diperpanjang kembali oleh pemerintah pusat hingga tanggal 9 agustus 2021. Pandemi Covid-19 merupakan musibah seluruh dunia. Seluruh segmen kehidupan manusia mengalami dampak pandemi Covid-19. Tanpa kecuali sektor Pendidikan. Pemerintah kembali memutuskan untuk melaksanakan pembelajaran secara dalam jaringan atau synchronous (Wiguna, 2020). banyak negara memutuskan untuk menutup sekolah untuk mengurangi kontak secara langsung dan untuk mencegah terjangkit virus Covid-19 atau tetap harus membuka sekolah dalam rangka survive para pekerja dalam menjaga keberlangsungan ekonomi (Syah, 2020).

Ada dua dampak bagi keberlangsungan pendidikan yang disebabkan oleh pandemi Covid-19. Pertama adalah dampak jangka pendek, yang dirasakan oleh banyak keluarga di Indonesia baik di kota maupun di desa. Di Indonesia banyak keluarga yang kurang familier melakukan sekolah di rumah. Bersekolah di rumah bagi keluarga Indonesia adalah kejutan besar khususnya bagi produktivitas orang tua yang biasanya sibuk dengan pekerjaannya di luar rumah.

Begitu pula dengan permasalahan psikologis anak usia dini atau peserta didik yang terbiasa belajar secara konvensional atau tatap muka dengan guru-guru yang ada di sekolah (Ekaningtyas, 2020). Seluruh elemen pendidikan secara kehidupan sosial terdampak pandemi covid-19. Pelaksanaan pembelajaran berlangsung dengan cara dalam jaringan. Proses ini berjalan pada skala yang belum pernah dilaksanakan dan terjadi sebelumnya. Tak terkecuali di pelosok desa terpencil yang berpenduduk usia sekolah sangat padat menjadi serba kebingungan, sebab infrastruktur informasi teknologi sangat terbatas (Salsabila et al., 2020). Penilaian siswa secara online dan banyak trial and error dengan sistem yang tidak ada kepastian, malah banyak penilaian yang yang dilaksanakan secara subyektif. Kedua adalah dampak jangka panjang. Banyak kelompok masyarakat di Indonesia yang akan terpapar dampak jangka panjang dari covid-19 ini. Dampak pendidikan dari sisi waktu jangka panjang adalah aspek keadilan dan peningkatan ketidaksetaraan antar kelompok masyarakat dan antardaerah di Indonesia (Wiguna, 2020). 
Di sektor pendidikan, pemerintah menginformasikan melalui Kementerian Pendidikan dan Kebudayaan telah menerapkan kebijakan pembelajaran dalam jaringan atau belajar dengan cara online dengan cara belajar dari rumah terutama bagi satuan pendidikan yang berada di wilayah zona kuning, oranye dan merah. Hal ini mengacu pada Keputusan Bersama Menteri Pendidikan dan Kebudayaan, Menteri Agama, Menteri Kesehatan dan Menteri Dalam Negeri tentang Panduan Penyelenggaraan Pembelajaran pada Tahun Ajaran 2020/2021 dan Tahun Akademik 2020/2021 di masa Covid-19. Bagi satuan pendidikan yang berada di zona hijau, dapat melaksanakan pembelajaran tatap muka dengan tetap memperhatikan protokol kesehatan.

Belajar dari Rumah (BDR) dilaksanakan dengan sistem Pembelajaran Jarak Jauh (PJJ). Dalam Undang-undang No. 20 tahun 2003 pasal 1 ayat 15 (Kemdikbud, 2003), dijelaskan bahwa PJJ adalah pendidikan yang peserta didiknya terpisah dari pendidik dan pembelajarannya menggunakan berbagai sumber belajar melalui teknologi komunikasi, informasi dan media lain. Dalam pelaksanaannya, PJJ dibagi menjadi dua pendekatan, yaitu pembelajaran jarak jauh dalam jaringan (daring) dan pembelajaran jarak jauh luar jaringan (luring). Dalam pelaksanaan PJJ, satuan pendidikan dapat memilih pendekatan (daring atau luring atau kombinasi keduanya) sesuai dengan karakteristik dan ketersediaan, kesiapan sarana dan prasarana (Asmuni, 2020).

Dari pemaparan diatas menyatakan bahwa salah satu jenis pembelajaran jarak jauh adalah pembelajaran dalam jaringan (daring). Sistem pembelajaran daring merupakan pembelajaran yang tidak melaksanakan tatap muka secara langsung antarguru dan peserta didik, melainkan menggunakan teknologi yakni internet (Widiyono, 2020). Guru dan orang tua peserta didik menyepakati waktu dalam pelaksanaan pembelajran. Baik kesepakatan dalam menggunakan berbagai applikasi seperti whatsapp, telegram, zoom meeting, google meet, ruang guru atau aplikasi lainnya yang disepakati bersama. Menyikapi fakta yang dialami oleh masyarakat di PAUD bernuansa Hindu di kota mataram sebagian orang tua tidak memiliki perangkat handphone atau komputer untuk menunjang pembelajaran daring (Sunariyadi \& Andari, 2021). Terlebih bagi peserta didik dengan kondisi demikian membuat mereka kebingungan dalam menghadapi pembelajaran daring. Pada satu sisi dihadapkan pada pendidikan harus tetap berjalan sesuai dengan UUD 1945 yang menyatakan bahwa setiap warga berhak mendapatkan pendidikan.

Dalam penelitian ini akan membahas terkait hambatan yang dialami oleh guru dalam pelaksanaan pembelajaran pada masa pandemi Covid-19. Untuk memberikan 
jawaban atas rumusan masalah yang telah diterakan dalam penelitian ini akan digunakan teori fungsional. Teori fungsional struktural adalah suatu bangunan teori yang paling besar pengaruhnya dalam ilmu sosial di abad sekarang. Pemikiran struktural fungsional sangat dipengaruhi oleh pemikiran biologis, diumpamakan sebuah struktur sebagai organisme biologis yang tersusun dari organ atau bagian yang saling berhubungan dan ketergantungan. Ketergantungan tersebut merupakan hasil atau konsekuensi agar struktur tersebut tetap ada dan dapat menjalankan fungsinya secara optimal. Serupa dengan pendekatan lainnya, pendekatan struktural fungsional ini juga bertujuan untuk mencapai keteraturan dalam tubuh struktur itu sendiri.

Fungsional struktural sering menggunakan konsep sistem sebagai sebuah organisasi dari keseluruhan bagian-bagian yang saling terkait dan tergantung, ketika membahas tentang struktur. Fungsional struktural akan digunakan sebagai instrumen dalam menilai pelaksanaan kebijakan dari Kementerian Pendidikan dan Kebudayaan RI perihal pembelajaran di rumah dalam masa pandemi Covid-19, sampai pada tingkat satuan pendidikan anak usia dini (PAUD). Implementasi kebijakan memerlukan sebuah struktur dengan sistem yang optimal dari Dinas Pendidikan pusat, provinsi dan kota, sampai pada masing-masing satuan pendidikan khususnya guru dan orang tua siswa sebagai ujung tombak kebijakan pembelajaran di rumah. Teori fungsional struktural akan digunakan dalam menganalisa dan menjawab pokok permasalahan, tentang implementasi dan pelaksanaan program pembelajaran di rumah pada lembaga pendidikan PAUD Kota Mataram dalam masa pandemi Covid-19. Bagaimana kebijakan ditindaklanjuti oleh Dinas Pendidikan dan Kebudayaan Kota Mataram.

\section{Metode}

Penelitian ini memiliki karakteristik yang bersifat eksploratif, dengan menekankan proses daripada produk, dengan kecenderungan menganalisis data secara induktif. Jenis penelitian ini menggunakan metode kualitatif. Penelitian ini telah dilaksanakan di Kota Mataram Propinsi Nusa Tenggara Barat dengan menyasar 13 lembaga pendidikan PAUD bernuansa Hindu yang ada di Kota Mataram. Pemilihan lokasi penelitian berdasarkan pertimbangan bahwa Kota Mataram memiliki penduduk dengan persentase paling tinggi diantara kabupaten kota yang ada di Pulau Lombok NTB. Sehingga dengan tingginya populasi penduduk beragama Hindu, Kota Mataram memiliki lembaga pendidikan PAUD paling banyak, dan layak digunakan sebagai lokasi penelitian. 
Penelitian ini merupakan jenis penelitian lapangan (field research), yang menerapkan teknis deskriptif kualitatif sebagai suatu strategi untuk menggali data yang berhubungan dengan peristiwa-peristiwa, tindakan dan makna yang menyertai tindakan tersebut dalam penyelenggaraan pendidikan pada lokasi penelitian. Pemilihan Informan dalam penelitian ini dengan mempertimbangkan pengetahuan atau pemahaman mendalam informan terhadap obyek yang dikaji, yang ditentukan secara purposive sampling. Selain itu memiliki sifat keterbukaan serta obyektif dalam mengungkapkan setiap fenomena yang berkaitan dengan penelitian. Informan yang dipilih adalah informan yang berasal dari Dinas Pendidikan Kota Mataram, penyelenggara PAUD Hindu, serta tenaga pendidik PAUD yang memiliki relevansi dengan obyek kajian penelitian ini.

\section{Hasil dan Pembahasan}

Kebijakan pemerintah dalam pencegahan terjadinya penularan Covid-19(Sari et al., 2020), berdampak pada usaha berbagai kementerian dalam mengakomodir dan mewujudkan segala pedoman, aturan, instrumen dan sarana prasarana penunjang di tingkat akar rumput (Saxena, 2020). Selain kajian-kajian dan penelitian singkat para akademisi di lapangan, sebagai dasar pertimbangan dalam memunculkan berbagai pedoman dan aturan, agar sebuah kebijakan dapat terimplementasikan secara maksimal. Kajian singkat dan research yang bersifat urgent dan mendesak sudah tentu memiliki keterbatasan-keterbatasan, karena harus segera diterapkan, mengingat dampak dari pandemi Covid-19 yang menyebar dengan cepat.

Dampak dari usaha pencegahan menyebarnya Covid-19 berdampak signifikan terhadap pelayanan pendidikan konvensional secara tatap muka yang harus dihentikan, dengan mengganti proses pembelajarannya menjadi pembelajaran daring dengan Belajar Dari Rumah (Wiguna \& Ekaningtyas, 2021). Terhitung dari dikeluarkannya Surat Edaran Menteri Pendidikan dan Kebudayaan Nomor 2 Tahun 2020 dan Nomor 3 Tahun 2020 (Kemdikbud, 2020), tentang Pencegahan dan Penanganan Covid-19 tertanggal 9 Maret 2020. Sampai pada Surat Edaran Mendikbud tentang Pembelajaran secara Daring dan Bekerja dari Rumah dalam Rangka Pencegahan Penyebaran Covid-19 (Nurkolis \& Muhdi, 2020). Kemudian berdasarkan Surat Keputusan Bersama 4 menteri, akhirnya sampai pada kebijakan di tingkat provinsi khususnya Provinsi NTB dengan dikeluarkannya Surat Edaran Nomor: 420/3266.UM/Dikbud dari Dinas Pendidikan dan Kebudayaan Provinsi NTB (Disdik NTB, 2020) 
Surat Edaran Nomor: 420/3266.UM/Dikbud dari Dinas Pendidikan dan Kebudayaan Provinsi NTB, menjadi jawaban dari kebingungan setiap satuan pendidikan khususnya PAUD yang ada di Kota Mataram, utamanya para pengelola PAUD baik itu kepala sekolah maupun guru. Berdasarkan pedoman yang ada sesuai instrumen dan ketentuan yang diberikan Dinas Pendidikan dan Kebudayaan Provinsi NTB, secara internal para pengelola satuan pendidikan PAUD mulai berbenah, mencurahkan ide, pemikiran, kreatifitas dan inovasi para kepala sekolah, guru dan tenaga kependidikan, termasuk pihak yayasan. Ditengah-tengah keterbatasan sumber daya para tenaga pendidik, pendanaan dan fasilitas yang dimiliki, masing-masing satuan pendidikan PAUD bernuansa Hindu yang ada di Kota Mataram.

Berbagai tantangan dalam proses penyesuaian masing-masing satuan pendidikan PAUD dialami oleh para pengelola pendidikan (Taufik, 2019). Karena keterbatasan sumber daya yang dimiliki setiap satuan pendidikan PAUD bernuansa Hindu di Kota Mataram, walaupun beberapa PAUD ada yang telah menerima dana operasional BOS, yang dapat dialokasikan untuk penyediaan fasilitas terkait protokol kesehatan (Wiguna, 2021). Seperti yang disampaikan oleh Yuni Karyani, S.Pd, Kepala Sekolah PAUD Gayatri. Berikut hasil kutipan wawancaranya:

"Mengenai dana, sekolah kita memang sudah dapet dari dinas, bantuan dana operasional sekolah (BOS). Dananya dihitung per siswa. Tapi dak bisa semua kita bisa pake buat beli alat itu (Protokol Kesehatan). Tempat cuci tangan yang ada wadah kakinya saja, paling murah sampai ratusan ribu, kaki penyangganya kan besi. Apalagi buat beli alat cek Thermogun itu.... Sementara baru kita bisa sediain tempat cuci tangan sama sabun cair, paling penting di depan pintu masuk itu .... Yang jaga, maksudnya yang petugas pantau protokol kesehatan, khusus dak ada, kadang giliran saja ngatur sesama guru disini."

Tanggapan serupa juga disampaikan oleh Ni Luh Putu Arini, S.Ag., S.Pd, Kepala Sekolah PAUD Sandat Kuning, perihal keterbatasan yang dimiliki sekolah menuju Fase Penyesuaian New Normal. Berikut hasil wawancara dengan Ni Luh Putu Arini, S.Ag., S.Pd:

“permakluman yah kita sekolah kecil, siswa juga tidak terlalu banyak, ibu (peneliti) kan sudah tahu sendiri. Selama ini fasilitas sudah kita berusaha penuhi, kalau tempat nyuci tangan (untuk siswa) dah dari dulu ada, tempat cuci tangan yang buat umum depan pintu sekolah juga sudah. Lumayan juga biaya.... Thermogun kita belum punya, mahal. Kabarnya dulu sampe diatas satu juta, skarang dah turun katanya. Tapi tetap mahal juga. Kalau poster cuci tangan, sudah kita tempel. sekat pembatas meja siswa kita belum ada, biar kita cuman ada 2 ruang blajar, tapi lumayan juga pasang yang pembatas itu, apalagi kalau pasang dari kaca" 
Lebih lanjut keluhan yang sama juga disampaikan oleh Ni Luh Ganti, S.H. Berikut hasil kutipan wawancara dengan beliau, selaku Kepala Sekolah TK. Saraswati:

"Kita dibawah yayasan, jadi tetap berjalan sesuai petunjuk arahan yayasan. Apalagi mengenai operasonal sekolah, untuk tempat cuci tangan sama cairan pembersih seperti yang diminta disekolah, sudah ada. Depan pintu masuk, termasuk spanduk himbauan menjaga kebersihan, yang cara cuci tangan, penggunaan masker. Tulisan kawasan wajib masker juga. Semprot disinfektannya samaan dengan ruanganruangan di kampus dan sekolah SMA, kita jadi satu areal disini. Jadi nunggu samaan disemprot semua, dak ada yang berkala, sesuai jadwal begitu. kalau antiseptik alkohol, handsanitizer sudah ada disediakan. Thermogun belum"

Informasi mengenai keterbatasan kemampuan sekolah dari Yuni Karyani, S.Pd, Ni Luh Putu Arini, S.Ag., S.Pd dan Ni Luh Ganti, S.H, selaku pemegang kebijakan sebagai kepala sekolah, juga didukung oleh para informan kepala sekolah lainnya. Hal serupa dijumpai pada sebagian besar sekolah PAUD bernuansa Hindu, yang ada di Kota Mataram sebagai lokasi penelitian. Keterbatasan kemampuan pihak satuan pendidikan dalam pengadaan fasilitas protokol kesehatan, seperti alat pendeteksi suhu tubuh (Thermogun), pembuatan sekat pembatas meja siswa dan meja guru, sosialisasi atau himbauan protokol kesehatan secara elektronik atau verbal, penyediaan face shield dari sekolah, guru atau petugas khusus pemantau protokol kesehatan, dan fasilitas lainnya, sampai pada penyemprotan disinfektan yang terjadwal dan berkala.

Koordinasi dan komunikasi secara eksternal menjadi salah satu faktor penting, dalam pemenuhan fasilitas yang menunjang penerapan protokol kesehatan. Koordinasi pihak pengelola satuan pendidikan yakni kepala sekolah dan ketua yayasan dengan institusi atau dinas terkait (Ni'mah, 2016) seperti Dinas Kesehatan Kota Mataram, pemerintah Provinsi NTB atau Kota Mataram sampai tingkat Kelurahan, serta para donatur dari lingkungan satuan pendidikan. Berikut hasil kutipan wawancara dengan Ida Ayu Anom Santiani, S.E, sebagai Kepala Sekolah PAUD Cahaya Ananda:

"kita berusaha tempuh hubungan keluar juga, ngubungin apa ada kesempatan buat proposal penyediaan sarana protokol kesehatan. Seperti yang alat semprot disinfektan kita bisa punya lewat sumbangan dari luar sekolah. Punya sendiri jadi bisa terjadwal sesuai keperluan kita disini semprotnya. Thermogun juga sama prosesnya. Kita coba dari dinas kesehatan, Puskesmas disini, termasuk donatur tetap kita, yah lewat ketua yayasan juga ikut andil. Sampai kita sudah buat video ilustrasi kegiatan bimbingan belajar, agar bisa sosialisasikan pada pihak luar sekolah kita terapkan protokol kesehatan"

Masing-masing pengelola satuan pendidikan PAUD, menghadapi kondisi dan situasi yang terkadang berbeda. Seperti yang disampaikan oleh Ni Luh Pura Kariani, S.Pd, Kepala Sekolah TK Cempaka Harum. Berikut hasil kutipan wawancaranya: 
“ada pengalaman kita sebelumnya, waktu kita disini (internal sekolah dan orang tua siswa) sepakat melaksanakan bimbingan sekolah, bukan tatap muka, dari dinas

datang ke sekolah. Setelah itu, kita pulangkan anak-anak. Sementara kita belum diijinkan, biarpun dengan bentuk pelayanan bimbingan sekolah. Mungkin kita juga dak sampaikan ke pengawas dari dinas (Dikbud Kota Mataram) ”.

Namun mengenai pelaksanaan protokol kesehatan, Ni Luh Pura Kariani, S.Pd menyampaikan adanya koordinasi yang intens dengan pihak Kelurahan melalui yayasan. Berikut hasil kutipan wawancaranya:

"untuk disinfektan di ruangan, di sekolah kita, rutin dapat. Kebetulan juga ketua yayasan kita kepala lingkungan disini, jadi tetap disertakan di penjadwalan dari Kelurahan sini. Poster edukasi juga dapat dari Puskesmas, kalau ada poster baru, pasti dikasikan disini juga. Yang langkah-langkah cuci tangan, pencegahan Covid-19, etika batuk dan bersin, sama tentang kesehatan"

Komunikasi dan koordinasi menjadi penting dalam kemampuan satuan pendidikan (Purandina, 2021) untuk mempersiapkan dirinya menuju Fase Penyesuaian Kebiasaan Baru New Normal. Terpenting lagi menghindari terjadinya kesalahan dalam hal penerapan kebijakan pemerintah dalam pencegahan penyebaran Covid-19, maupun pengambilan kebijakan internal sekolah. Seperti yang disampaikan dalam hasil wawancara dengan para informan, khususnya informan Ni Luh Pura Kariani, S.Pd. Karena usaha sekolah dalam memenuhi aspirasi dan kebutuhan masyarakat yakni para orang tua siswa akan pelayanan pendidikan, belum tentu sesuai dengan prosedur yang telah ditetapkan oleh pemerintah, seperti dalam Surat Edaran Nomor: 420/3266.UM/Dikbud dari Dinas Pendidikan dan Kebudayaan Provinsi NTB.

Secara internal para pemangku kebijakan seperti kepala sekolah, ketua yayasan, tenaga pendidik dan kependidikan juga memiliki komitmen dan pemahaman yang berbeda-beda, dalam menyikapi kebijakan khususnya penerapan Fase Transisi menuju Fase Penyesuaian New Normal. Menjadi tantangan tersendiri bagi para pemangku kebijakan yakni kepala sekolah di tingkat satuan pendidikan PAUD, untuk memberikan pemahaman yang benar dan menumbuhkan komitmen para tenaga pendidik dan kependidikan yang dimilikinya, agar sekolah dapat berjalan dan berhasil menerapkan Fase Penyesuaian New Normal.

Tantangan juga muncul dari orang tua siswa sebagai pengguna manfaat pelayanan pendidikan, yang terkadang sulit untuk melaksanakan bimbingan dan panduan bagi anakanaknya dirumah (Sunariyadi, \& Andari, 2021), untuk menerapkan proses Belajar Dari Rumah (BDR). Menjadi faktor penyebab para orang tua atau komite sekolah, memaksakan agar pihak satuan pendidikan membuka layanan pembelajaran kembali. 
Menjadi latar belakang satuan pendidikan mengeluarkan kebijakan, melaksanakan program bimbingan sekolah atau bentuk lain yang tidak sejalan dengan kebijakan pemerintah.

Berikut hasil kutipan wawancara dengan Ni Luh Pura Kariani, S.Pd, Kepala Sekolah TK. Cempaka Harum, berkaitan dengan keinginan orang tua siswa:

"mulai banyak keluhan ibu-ibu, belajar dirumah belajar daring itu susah, anakanaknya pada bebel (sulit diatur) buat kerjakan tugas sekolah, apalagi belajar. Pake HP saja maunya. Kami disekolah sebenarnya antara ya dan tidak, gemana caranya, kasihan juga orang tuanya. Jadi kita buka layanan bimbingan sekolah, jadi seperti yang cerita tadi jadinya (sidak dinas pendidikan)"

Keefektifan dari sistem pembelajaran tatap muka yang selama ini telah dijalankan para tenaga pendidik dan diikuti oleh siswa, memang jauh berbeda dengan sistem pembelajaran daring. Kalaupun untuk pembelajaran BDR, tetap harus ada pembimbingan, mau tidak mau akan dibimbing oleh orang tua siswa di rumah. Permasalahan muncul ketika orang tua tidak memiliki kompetensi mengajar, dan dalam kurun waktu yang cukup lama di rumah, anak-anak mulai bosan dan memerlukan interaksi dengan kawan-kawannya di sekolah. Berbagai faktor lain seperti suasana rumah yang berbeda dengan lingkungan sekolah bersama teman-teman, kebersamaan dalam proses pembelajaran dengan jiwa kompetitor antar siswa, dan berbagai penyebab lainnya juga menjadi hambatan pelaksanaan Belajar Dari Rumah (BDR) dan daring.

Kesulitan pembelajaran daring atau Belajar Dari Rumah (BDR) yang harus dilaksanakan dan dibimbing oleh orang tua anak di rumah (Zaini \& Soenarto, 2019), juga disampaikan oleh Made Suseni salah seorang tenaga pendidik PAUD Cahaya Ananda. Berikut hasil kutipan wawancaranya:

"Sekolah di saya juga nerapkan bimbingan sekolah, tapi kita wanti-wanti sekali sama orang tua, ini kan keinginan kuat dari mereka, kami hanya fasilitasi. Keluhan ibu-ibu, susahnya ngajarin anak dirumah, sampe stres katanya. Saya sih senyum aja dengerinnya. Pihak sekolah minta mereka (orang tua) tanda tangan pernyataan meterai, takut kita nanti dituntut kalau ada apa-apa. Tapi ibu kepala (Kepala Sekolah PAUD Cahaya Ananda), tetap koordinasi dengan pengawas sekolah (Dinas Dikbud) dan yayasan. Makanya kita bikin rekaman ilustrasi kegiatan bimbingan belajar yang nerapkan protokol kesehatan, ibu (Kepala Sekolah PAUD Cahaya Ananda) juga sediakan Thermogun, Handsanitizer"

Berdasarkan hasil wawancara dengan para informan mengenai keluhan orang tua dan usaha pihak satuan pendidikan untuk mengakomodir permintaan orang tua, memerlukan adanya kesamaan pemikiran dan pemahaman antara masyarakat, satuan pendidikan dan pemerintah. Menghindari adanya kesalah pamahan dan kurang tanggap 
antara pemerintah yakni Dinas Pendidikan dan Kebudayaan Kota Mataram atau dinas terkait, dengan satuan pendidikan PAUD sebagai ujung tombak pelayanan pendidikan.

Berbagai kendala komunikasi dengan pihak pemerintah, seperti dengan Dinas Pendidikan dan Kebudayaan, Dinas Kesehatan, dan pemerintah Provinsi NTB atau Kota Mataram, juga dialami para pengelola satuan pendidikan PAUD. Berikut hasil wawancara dengan Sri Yuni Susilawati, S.Pd, Kepala Sekolah PAUD Dewi Ratih:

"Saya maklum dinas (Dinas Dikbud Kota Mataram) banyak yang diurus ya. Kita sekolah kecil, ya sebisanya memenuhi yang harus ada di sekolah. Kalau tempat nyuci tangan, cairan anti septik Handsanitizer, ada kita bisa usahakan. Tapi kalau yang mahal (Thermogun, sekat meja) kita coba lewat pengawas dinas, tapi belum ada katanya buat yang PAUD. Ngajukan ke pemerintah kota (Kota Mataram) kita coba juga, syarat-syaratnya harus ada macem juga, masih belum ada informasinya dapat apa tidak kita. Apa mungkin dananya sudah abis apa gemana untuk ajukan bantuan itu (fasilitas protokol kesehatan). Maklum kita sekolah kecil, bisa jadi diutamain yang siswa banyak duluan"

Sependapat dengan ibu Kepala Sekolah PAUD Dewi Ratih, Sri Yuni Susilawati, S.Pd, informasi yang senada juga peneliti dapatkan dari beberapa Kepala Sekolah PAUD yang lain, khususnya PAUD yang masih memiliki sarana dan prasarana sekolah minim. Kurangnya informasi dan sosialisasi tentang instansi atau dinas dan bidang apa saja, yang memberikan bantuan dalam hal penyediaan fasilitas protokol kesehatan juga menjadi permasalahan lain. Karena terkadang para pengelola satuan pendidikan PAUD masih bingung, kemana mereka harus mengajukan permohonan bantuan, yang berasal dari pihak pemerintah.

Hambatan atau kendala yang dihadapi oleh satuan pendidikan PAUD, dalam menerapkan Fase Transisi, sesuai dengan kebijakan Dinas Pendidikan dan Kebudayaan Provinsi NTB, sesuai dengan Teori Implementasi Kebijakan akan dilihat dari empat variabel yakni komunikasi, sumberdaya, disposisi, dan struktur birokrasi. Karena menjadi indikator penting bagi keberhasilan sebuah kebijakan dapat diterapkan dengan baik, jika implementor mengetahui tujuan dan sasaran serta apa yang harus dilakukan untuk mencapainya. Untuk dapat mencapai sasaran kebijakan. implementor juga harus memiliki sumber daya yang cukup, dengan kesamaan perspektif dari segenap struktur dalam implementor akan kebijakan yang dituju, serta tidak dipersulit oleh birokrasi yang rumit.

Pertama dalam variabel komunikasi, berdasarkan data lapangan diperoleh kesimpulan bahwa komunikasi internal satuan pendidikan secara umum telah terimplementasikan secara optimal. Dilihat dari komunikasi antar kepala sekolah dengan tenaga kependidikan, kepala sekolah dengan para tenaga pendidik, kepala sekolah dengan 
yayasan. Sebagai sebuah struktur, implementator dalam hal ini kepala sekolah secara optimal memberikan arahan kepada guru dan operator sekolah, tentang tujuan dan sasaran kebijakan sesuai Surat Edaran Nomor: 420/3266.UM/Dikbud dari Dinas Pendidikan dan Kebudayaan Provinsi NTB.

Menghindari adanya distorsi implementasi kebijakan dari pelaksanaan panduan penyelenggaraan pembelajaran pada Tahun Ajaran 2020/2021 di masa pandemi Covid19, kepala sekolah bersama-sama dengan para guru, operator sekolah dan ketua yayasan, mengkoordinasikan 2 instrumen yang ditetapkan dalam pedoman. Membagi uraian kerja berdasarkan berbagai indikator yang ada dalam, pedoman Fase Transisi dan Fase Penyesuaian New Normal.

Operator bertugas melaporkan perkembangan sekolah dengan mengisi atau input data periksa pada laman Data Pokok Pendidikan (Dapodik) Kemendikbud, untuk mengetahui kesiapan satuan pendidikan pada Fase Transisi menuju Fase Transisi dan Fase Penyesuaian New Normal. Guru memiliki tugas pokok untuk menyiapkan materi esensi dan non esensi, menjadi bahan ajar dan penugasan pembelajaran kegiatan Belajar Dari Rumah (BDR), termasuk untuk pembelajaran tatap muka pada Fase Penyesuaian New Normal. Selain itu guru dan operator juga membantu pelaksanaan kebijakan internal oleh kepala sekolah.

Sedangkan kepala sekolah dan ketua yayasan berkonsentrasi pada usaha sekolah dalam mempersiapkan segala fasilitas penunjang protokol kesehatan, seperti tempat cuci tangan dan sabun, penyediaan cairan antiseptik (handsanitizer), masker atau face shield, pembatas meja siswa atau guru, alat pengecek suhu badan (Thermogun), poster edukasi kesehatan dan kebersihan, termasuk poster pencegahan Covid-19, serta fasilitas lainnya. Program kerja lainnya adalah bersama-sama guru dan operator sekolah, mempersiapkan SOP atau prosedur penerimaan siswa memasuki lingkungan sekolah, pendampingan siswa di dalam sekolah sampai siswa dijemput kembali oleh orang tua atau pihak keluarga, selain penjadwalan dan pengaturan jumlah siswa dalam waktu yang sama di sekolah.

Dukungan sumber daya yang dimiliki implementator, menjadi variabel kedua yang akan dianalisa dari data lapangan yang telah diperoleh peneliti. Berdasarkan data, mayoritas dari 13 satuan pendidikan PAUD bernuansa Hindu yang ada di Kota Mataram, masih belum memiliki sumber daya yang cukup mapan. Mayoritas PAUD hanya memiliki tenaga pendidik dengan jumlah yang minim, terdapat 7 sekolah PAUD yang memiliki tenaga pendidik 2 sampai 3 orang, 4 sekolah PAUD yang memiliki tenaga 
pendidik 4 sampai 5 orang, dan hanya 2 sekolah PAUD yang memiliki tenaga pendidik diatas 6 orang.

Hampir seluruh satuan pendidikan PAUD dari segi kompetensi, para tenaga pendidiknya belum memiliki kompetensi yang cukup, dalam hal pembelajaran daring atau sistem Belajar Dari Rumah (BDR) (Mundia Sari \& Setiawan, 2020). Belum ada mengikuti pelatihan pembelajaran daring atau sistem Belajar Dari Rumah (BDR), sebelum masa pandemi Covid-19 merebak di dunia. Pembelajaran daring dan mediamedia pendukung pelaksanaan daring baru dipelajari secara individu dan autodidak, melalui youtube dan webinar yang diadakan oleh Perguruan Tinggi dan lembaga pendidikan lainnya. Para tenaga pendidik PAUD cenderung menggunakan aplikasi HP seperti Whatsapp dan Zoom.

Sumber daya finansial dalam mendukung ketersediaan fasilitas protokol kesehatan bagi warga sekolah, menjadi permasalahan pokok pengelola PAUD. Di satu sisi para pengelola masih memiliki tanggungjawab dalam pembiayaan operasional sekolah, berupa pembayaran gaji para tenaga pendidik dan kependidikannya, selain operasional sekolah seperti ATK pengadministrasian sekolah, pembayaran listrik, PDAM, dan operasional lainnya. Sedangkan pada sisi yang lain, harus menyediakan fasilitas pendukung protokol kesehatan.

Minimnya sumberdaya kompetensi dan sumber daya finansial dari masingmasing satuan pendidikan PAUD bernuansa Hindu dalam penelitian ini, memberikan pengaruh yang besar pada efektifitas pelaksanaan kebijakan pemerintah pada Fase Transisi. Terlebih keinginan pemerintah yang ingin mewujudkan, agar setiap satuan pendidikan PAUD dapat memasuki Fase Penyesuaian New Normal mulai bulan Januari 2021.

Data informan di tiga satuan pendidikan PAUD yakni TK. Cempaka Harum, TK. Amdani dan PAUD Dharma Gita, mengenai perbedaan pandangan akan kebutuhan masyarakat akan pelayanan pembelajaran tatap muka dan pembuat kebijakan yakni Dinas Pendidikan dan Kebudayaan Kota Mataram. Kebijakan harus didukung oleh kesamaan perspektif yang dimiliki oleh implementator yaitu para pengelola PAUD dengan pembuat kebijakan dalam hal ini Dinas Pendidikan dan Kebudayaan Provinsi NTB atau Kota Mataram. Keinginan masyarakat yang belum terakomodir dalam kebijakan pemerintah, sehingga satuan pendidikan melalui komite sekolah dan yayasan melaksanakan program bimbingan sekolah, yang ternyata belum memenuhi kriteria yang tercantum dalam kebijakan Fase Transisi. 
Diperlukan adanya kajian untuk menemukan kesamaan perspektif antara masyarakat, implementator yakni pengelola PAUD dan pembuat kebijakan dalam hal ini Dinas Pendididkan dan Kebudayaan Provinsi NTB. Agar sasaran dan tujuan kebijakan seperti yang terkandung dalam Surat Edaran Nomor: 420/3266.UM/Dikbud dari Dinas Pendidikan dan Kebudayaan Provinsi NTB dapat tercapai secara optimal, tanpa munculnya konflik antara pemerintah dengan satuan pendidikan PAUD yang mencoba memfasilitasi kepentingan masyarakat dan masyarakat yaitu orang tua siswa yang berkepentingan akan layanan pendidikan.

Struktur birokrasi seperti yang disampaikan para informan di PAUD bernuansa Hindu di Kota Mataram, walaupun tidak memberikan hambatan yang sangat berarti bagi pelaksanaan kebijakan, namun menjadi faktor penghambat dalam penelitian ini. Keterbatasan mayoritas satuan pendidikan PAUD baik pada sumber daya kompetensi, sumber daya manusia, maupun sumber daya finansial, semakin dipersulit dengan kurangnya informasi dan birokrasi pemerintahan, mengenai penyediaan bantuan pemenuhan fasilitas protokol kesehatan di lingkungan sekolah.

\section{Kesimpulan}

Hambatan yang dialami satuan pendidikan ada pada minimnya sumber daya yang dimiliki implementator, baik sumber daya kompetensi tenaga pendidik dalam hal pembelajaran daring atau sistem Belajar Dari Rumah (BDR), maupun sumber daya finansial dalam mendukung ketersediaan fasilitas protokol kesehatan bagi warga sekolah. Perbedaan perspektif dalam menanggapi kebutuhan siswa antara pengelola PAUD sebagai implementator, dengan Dinas Pendidikan dan Kebudayaan Provinsi atau Kota sebagai pembuat kebijakan daerah. Keterbatasan informasi dan birokrasi pemerintahan, mengenai penyediaan bantuan pemenuhan fasilitas protokol kesehatan sekolah. Sehingga berpengaruh besar pada efektifitas pelaksanaan kebijakan pemerintah pada Fase Transisi.

Implementasi pembelajaran jarak jauh ini seringkali ditemukan kendala ataupun ketidaksesuaian dengan pembelajaran yang seharusnya, banyak yang mengira tanggung jawab pengajar dalam melaksanakan pembelajaran daring lebih ringan ketimbang dengan Pembelajaran konvensional. Penggunaan media internet atau e-learning memiliki kendala yang cukup besar, koneksi jaringan dan kesalahan teknis seperti server error sehingga menghambat keberhasilan tujuan pembelajaran. Maka guru diharapkan memiliki kreativitas dalam menyampaikan materi pembelajaran dengan menarik minat belajar siswa sehingga memotivasi belajar siswa dan berdampak kepada peningkatan 
prestasi siswa. serta sangat diperlukan bantuan dari pemerintah untuk membantu menunjang fasilitas yang bisa mendukung pelaksanaan pembelajaran daring ini. Dengan begitu, pelaksanaan pembelajaran jarak jauh dapat berjalan dengan lancar dan efektif.

\section{Daftar Pustaka}

Arta wiguna, I. bagus alit. (2020). Efektivitas Penerapan Metode Hypnoteaching Dalam Meningkatkan Aktivitas Belajar Siswa. PEMBELAJAR: Jurnal Ilmu Pendidikan, Keguruan, Dan Pembelajaran, 4(2). https://doi.org/10.26858/pembelajar.v4i2.13006

Asmuni, A. (2020). Problematika Pembelajaran Daring di Masa Pandemi Covid-19 dan Solusi Pemecahannya. Jurnal Paedagogy, 7(4). https://doi.org/10.33394/jp.v7i4.2941

Surat Edaran Nomor: 420/3266.UM/Dikbud, (2020).

Ekaningtyas, N. L. D. (2020). Pandemi Covid-19: Dampak Psikologis Dan Upaya Menjaga Kesehatan Mental Masyarakat. In COVID-19: Perspektif Agama dan Kesehatan.

Hanifah Salsabila, U., Irna Sari, L., Haibati Lathif, K., Puji Lestari, A., \& Ayuning, A. (2020). Peran Teknologi Dalam Pembelajaran Di Masa Pandemi Covid-19. AlMutharahah: Jurnal Penelitian Dan Kajian Sosial Keagamaan, 17(2). https://doi.org/10.46781/al-mutharahah.v17i2.138

Surat Edaran Menteri Pendidikan dan Kebudayaan Nomor 2 Tahun 2020, (2020).

Kementrian Pendidikan dan Kebudayaan. (2003). Undang-undang Sistem Pendidikan Nasional No 20 Tahun 2003. Kemendikbud, 18(1).

Mundia Sari, K., \& Setiawan, H. (2020). Kompetensi Pedagogik Guru dalam Melaksanakan Penilaian Pembelajaran Anak Usia Dini. Jurnal Obsesi : Jurnal Pendidikan Anak Usia Dini, 4(2). https://doi.org/10.31004/obsesi.v4i2.478

Ni’mah, F. I. (2016). Manajemen Pembelajaran Jarak Jauh (Distance Learning) Pada Homeschooling "Sekolah Dolan". Manajemen Pendidikan, 25(1).

Nurkolis, N., \& Muhdi, M. (2020). Keefektivan Kebijakan E-Learning berbasis Sosial Media pada PAUD di Masa Pandemi Covid-19. Jurnal Obsesi: Jurnal Pendidikan Anak Usia Dini, 5(1). https://doi.org/10.31004/obsesi.v5i1.535

Purandina, I. P. Y. (2021). STRATEGI KOMUNIKASI INTERPERSONAL GURU PADA PENDIDIKAN ANAK USIA DINI SELAMA PEMBELAJARAN JARAK JAUH. Kumarottama: Jurnal Pendidikan Anak Usia Dini, 1(1), 19-35. 
Sari, W., Rifki, A. M., \& Karmila, M. (2020). Analisis Kebijakan Pendidikan Terkait Implementasi Pembelajaran Jarak Jauh Pada Masa Darurat Covid 19. Jurnal MAPPESONA, 1 .

Saxena, S. K. (2020). Coronavirus Diseas 2019 (COVID-19): Epidemoogy, Pathogenis, Diagnosis, and Therapeutics.

Sunariyadi, N. S., \& Andari, I. A. M. Y. (2021). IMPLIKASI POLA ASUH ORANG TUA DALAM PENUMBUHKEMBANGAN KARAKTER ANAK USIA DINI. Kumarottama: Jurnal Pendidikan Anak Usia Dini, 1(1), 49-60.

Syah, R. H. (2020). Dampak Covid-19 pada Pendidikan di Indonesia: Sekolah, Keterampilan, dan Proses Pembelajaran. SALAM: Jurnal Sosial Dan Budaya Syar-I, 7(5). https://doi.org/10.15408/sjsbs.v7i5.15314

Taufik, A. (2019). Perspektif tentang perkembangan sistem pembelajaran jarak jauh di kabupaten kutai kartanegara kalimantan timur. Jurnal Pendidikan \& Konseptual, 3(2), 88-98.

Widiyono, A. (2020). Efektifitas Perkuliahan Daring (Online) pada Mahasiswa PGSD di Saat Pandemi Covid 19. Jurnal Pendidikan, 8(2). https://doi.org/10.36232/pendidikan.v8i2.458

Wiguna, I. B. A. A., \& Ekaningtyas, N. L. D. (2021). STRATEGI ORANG TUA DALAM MENDAMPINGI ANAK USIA DINI BELAJAR DARING DI RUMAH. PRATAMA WIDYA: JURNAL PENDIDIKAN ANAK USIA DINI, 6(1), 86-95. http://www.ejournal.ihdn.ac.id/index.php/PW/article/view/2141

Wiguna, I. B. A. A. (2021). Kepemimpinan Kepala Sekolah PAUD Di Masa Pandemi Covid-19. In Prosiding Seminar Nasional Institut Agama Hindu Negeri Tampung Penyang Palangka Raya, 1(1), 221-233.

Wiguna, Ida Bagus Alit Arta. (2020). Student responses on the application of Hypnoteaching method to increase learning activities. Jurnal Pendidikan Dan Pengajaran, 53(2). https://doi.org/10.23887/jpp.v53i2.23346

Zaini, M., \& Soenarto, S. (2019). Persepsi Orangtua Terhadap Hadirnya Era Teknologi Digital di Kalangan Anak Usia Dini. Jurnal Obsesi : Jurnal Pendidikan Anak Usia Dini, 3(1). https://doi.org/10.31004/obsesi.v3i1.127 